\title{
Digital Parenting: The Use of Gadgets in Instilling Socio-Cultural Values in Children
}

\author{
Ria Astuti ${ }^{1, *}$ Yuli S. Hijriyani ${ }^{2}$ Thorik Aziz ${ }^{3}$ Khoirul Bariyyah ${ }^{4}$ \\ IIAIN Madura, Pamekasan, Indonesia \\ ${ }^{2}$ IAIN Ponorogo, Ponorogo, Indonesia \\ ${ }^{3}$ IAIN Madura, Pamekasan, Indonesia \\ ${ }^{4}$ SMPN 1 Bringin, Semarang, Indonesia \\ *Corresponding author. Email: ria.astuti@iainmadura.ac.id
}

\begin{abstract}
This study aims to describe people's upbringing in introducing sociocultural values to early childhood using gadgets. The type of this research is qualitative description by using interviews of 10 respondents, observation, and documentation. The design of this study was qualitative with descriptive approach. The research sampling was determined by purposive sampling. The data was obtained by collecting, analyzing, and drawing conclusions by indepth interview, observation, and documentation. There were 10 respondents as purposive samples in this research. The collected data was analyzed by data reduction, data display and conclusion. The results showed that nurturing in this era could not be separated from digital influences. Parents felt helped by the presence of gadgets in instilling sociocultural values for children. The sociocultural values were instilled not only by the practice of worship, but also moral values such as: saying sorry, thank you, and throwing garbage in its place. Gadgets could also provide examples to children about sociocultural teachings, such as prayer
\end{abstract}

Keywords: Digital parenting, Sociocultural values, Children.

\section{INTRODUCTION}

Time is growing rapidly and technology is developing with increasingly sophisticated features day by day. Indonesia is entering the era of Industrial revolution 4.0, even some of the world has entered the era of society 5.0. Signs of the 4.0 industrial revolution era can be seen in the phenomenon of digitalization of information and the use of artificial intelligence in various sectors of human life to carry out certain functions and tasks. In addition, the era of information can be accessed easily. It can even be accessed with various user conditions and only with a finger. It is based on the research conducted by Baharun \& Finori with the title Smart Techno Parenting: Alternatif Pendidikan Anak Pada Era Teknologi Digital (Alternative Education for Children in Digital Technology Era), showing that children born and living in this era are known as digital native or digital generation (Baharun \& Finori, 2019).
The rapid development of digital technology requires parental supervision to help children filter out any information or applications which can be adapted to children's developmental stages.

Advances in digital media technology have made available various technological devices with uninterrupted options for parents and their children. Overall, technological advances in the present and past centuries have played an important role in the educational process. Apart from parents and schools, auditory and visual media are very influential on a child's learning curve (Yoruk \& Cankaya, 2013). The habits of parents and their attitudes towards the use of media technology on digital devices are likely to have an impact on children's habits (Lauricella, Wartela \& Rideout: 2015). How parents feel about the media, their moral standards, and attitudes toward media use at home are likely to influence the minds of their offspring. 
About $70 \%$ of parents in the United States (US) feel that computers are a useful aid for children's learning. The American Academy of Pediatrics recommends reducing the health risks of young children and adolescents, such as: affecting sleep, being exposed to inappropriate content, unknown contacts, and jeopardizing personal confidentiality and privacy Ameenuddin et al: 2016). The role of parents becomes difficult to carry out when guiding children to use technology media safely. Neumann suggests the use of technology for children under 8 years, in three dimensions: cognitive, affective and technical, while children use touch screen tablets such as the iPad (Neumann: 2015). It is expected that children tend to be less dependent on their parents in using digital devices as they grow from an early age (Yoruk\&Cankaya, 2013). Lauricella suggested that if parents use digital media devices such as televisions, computers, and smart gadgets to contribute to children's affective, cognitive and physical learning, they should let their children use them (Lauricella, Wartela\& Rideout: 2015).

The intensity of digital use, which includes gadgets, can have both positive and negative impacts for children. The negative impact of using gadgets in early childhood was revealed by Sundus (2017) in his research entitled "The Impact of Using Gadgets on Children". This study shows that the increasing use of gadgets from day to day causes technology addiction in early childhood and this has an impact on children's cognitive and motor skills. Even some parents equip their gadgets with internet access. Although it has benefits, it is undeniable that internet access has a negative impact on the process of early childhood development. The use of gadgets can even damage the morale and character formation of children that are not expected by parents. According to the results of research conducted by Meta Keumala, et al (2018), entitled "The Impacts of Gadget and Internet on the Implementation of Character Education on Early Childhood" shows that providing access to gadgets and the internet in early childhood can have positive and negative impacts. Children may have better motor skills, improved cognitive skills, and competitive skills, whereas, on the contrary, children may face serious problems such as speech delays, attention deficits, learning problems, even mental disorders that can impact their character.

This is also in line with the research conducted by Nirwana, et al (2018), entitled "The Effect of Gadget Toward Early Childhood Speaking Ability”, which states that the use of gadgets can slow children's speaking ability, especially children aged 3-4 years. This study examines the influence of gadgets on the speaking ability of early childhood, especially in the age range of 3-4 years. Children aged 3-4 years generally have enthusiasm in speaking; their curiosity tends to be greater, such as telling something that is happening around them to those closest to them. However, the presence of gadgets in this digital era has a negative effect on their speaking ability. The majority of children in Indonesia spend their time playing gadgets.

The use of gadgets in early childhood is still a controversy. However, a study written by Rafi Antar (2019) entitled "Exploring the Use of Electronic Media in Young Children's Lives and its Effects on Brain Development" shows that exposure to electronic media which includes gadgets changes several parts of the brain, which in turn affects the brain, behavior, cognitive, and social-affective development in children. Gadgets are considered to have a negative impact on children's development, can inhibit language and social development. When children use their gadgets to play games, watch videos and so on, it will take time for children to play and socialize with their peers and also prevent children from developing language, but on the other hand gadgets can also provide positive benefits.

A study conducted by DewiNilam Sari (2019) entitled "An Analysis of the Impact of the Use of Gadgets on Children's Language and Social Development" shows that many interesting features offered by gadgets often make children quickly recognize them. There are many impacts and benefits of gadgets, among others, to facilitate children's creativity and intelligence. As the application of coloring, learning to read and write letters certainly has a positive impact on children's brain development. Children do not need a lot of time and effort to learn to read and write on books or paper. Children will also be more excited to learn because such applications are usually equipped with interesting pictures. This certainly has a positive impact on children's brain development.

Early childhoods who use gadgets, in general, cannot be separated from parental involvement. Research conducted by Veronika Konok, et al (2020) entitled "Associations between Child Mobile Use and Digital Parenting Style in Hungarian Families" shows that parents can influence the use of gadgets in children, through attitudes, beliefs, role models, and parenting styles. Further findings show that children spend more 
time on gadgets if their parents are: more permissive, more authoritative and less authoritarian, have a stronger level of education; show greater attachment to their cell phones; and have a more positive attitude towards, and attribute less harm and more benefit to, device use early on.

The same thing was also expressed by Martina Smahelova, et al (2017), in their research entitled "Mediation of Young Children's Digital Technology Use: The Parents' Perspective". They revealed that the factors of parents who give gadgets to children are related to the age and gender of the parents, the education of the parents, the age and gender of the children, the socioeconomic status of the household, and the number of family members. In addition, it is also related to parents' perceptions of their children's digital skills, parents' media literacy, parents' digital skill level, children's motivation to use media, frequency of media use in the family, and parents' views on various digital effects on children. their child. At the sociocultural level, this research conducted by Smahelova shows that parents who give their children the use of the internet are influenced by the culture of their country and the level of welfare of their country.

As mentioned above, children born in this era are natives, so they cannot be separated from technological advances. Therefore, parents have a very important role in introducing gadgets to early childhood. This requires proper parenting, guiding and educating children in this digital age.

The study written by Sri Maisari and Sigit Purnama (2019) on "The Role of Digital Parenting on the Development of Logical Thinking of Children Aged 5-6 years in RA Bunayya Giwangan" shows that the application of digital parenting concepts includes: applying rules and agreements related to the use of gadgets, guiding and accompanying children, using parental control, and balancing the child's digital world with the real world; and the role of digital parenting towards children's logical thinking includes education as well as entertainment for children; stimulating logical thinking; controlling, guiding the child to use gadget wisely. In addition, there are some movies or applications that can be used effectively by parents in instilling sociocultural values for children. For example, the study written by Masrur \& Amri (2021) on Islamic education values on an animated movie of Nussa (episode of the obligation for prayer) show that the animated film Nusa and Rara, the episode of prayer must contain values from the concept of Sociocultural teachings, namely Akidah (faith), Sharia (law) and Morality. If parents are able to nurture and guide by choosing content that educates and implements life values, it is hoped that the child will become a person with character according to the expectation of the nation and religion.

The use of gadgets in early childhood is difficult to avoid after there are pros and cons in providing gadgets to early childhood. In life with a wider community, gadgets can also be used by parents in providing education, teaching and instilling sociocultural values in children. Based on some observations, researchers can see that gadgets in the form of I-Pad, television, and smartphones can help parents in introducing sociocultural values to children, such as children are able to pray independently, learn to pray and recite sholawat. Of course, the cultivation of sociocultural values is very important to be instilled in early childhood considering the fact that they have a sensitive period in which all aspects of development develop very rapidly. In addition, early childhood who have a solid foundation or foundation for the teachings of Islam, is believed to overcome the moral decadence that we often encounter.

This research is very important to study considering the fact that the use of gadgets in early childhood has always been controversial. From the above exposure, the researchers formulated the purpose of this study to describe how parenting parents in instilling Sociocultural values at an early age using gadget media.

\section{METHODS}

This type of research was qualitative. Qualitative research is defined as a methodology that provides the tools in understanding the meaning in depth relating to complex phenomena and their processes in the practice of social life. (Brady: 2015). This study aimed to define a specific phenomenon that is digital parenting especially on the use of gadget in instilling sociocultural values in children. Ounand Bach (2014) Qualitative methods are used to test and answer the question of how, where, what, when, and why a person acts in certain ways on a specific problem. This qualitative research is integrative holistic looking at reality in a complex whole (Mills, Durepos, \& Elden: 2010). Researchers chose quality research to look at phenomena that exist in the wider community. Through this study, researchers wanted to see how parenting in instilling sociocultural values in early childhood using gadget. This study was conducted in Madura on May to July 2021 involving 10 respondents 
that were parents who used gadget to instill sociocultural values toward their children.

Data collection techniques conducted by researchers to obtain data that is effective are done by interviewing 10 respondents from various backgrounds, cultures, social, and economic. The research was conducted with a structured interview and was conducted by utilizing the WhatsApp application on the gadget. To complement the existing data, researchers also conducted observations and documentation on respondents that could be reached easily. The study sample was determined by purposive sampling. Purposive sampling is a technique of sampling data sources with certain considerations, for example, the person who is considered to know the most about what we expect, so that it will facilitate researchers in exploring objects or social situations studied. (Sugiyono: 2016). Then the data that the researcher already had, had been collected, had been analyzed and drawn conclusions to answer the formulation of the problem that had been determined. The researcher analyzed the data by reading and sorting 10 answers in WhatsApp application from 10 respondents. After that, the step was to display the conversation between researcher and respondent which related to the issue of this study that was instilling sociocultural values by using gadget based on their experiences. Finally, the researcher compared it to Bandura theory and drew a conclusion for this research.

\section{RESULTS AND DISCUSSION}

\subsection{The Use of Technology by Parents and Children}

Children used gadgets every day for reasons as entertainment with the content which was limited by parents and only watching about sociocultural songs. The gadget used was their parents'. Gadgets were introduced to children from the age of 4 years. With gadgets, parents felt helpful, one of which is that children could memorize short verses (juz 30). Children are classified as digital natives because they can function gadgets independently. Through gadgets, we can teach and instill sociocultural values such as introducing God's creations, as creed values that are instilled in children, besides teaching and introducing prayer.

The values of faith are instilled in children by giving examples of prayer movements, besides providing istiqomah values such as always being disciplined in prayer times (magrib, isya, and subuh/fajr). The values of honesty arre also taught when a child made a mistake, such as being asked why he made a mistake, the reason why he made the mistake.

By watching YouTube, children can also recognize and practice sociocultural teachings, such as understanding that they must cover their genitals, etc.
However, it was limited in using gadgets as an effort to minimize addiction to gadgets (Halimah: Interview).

The use of various digital technologies in children bears a theoretical resemblance to the Social Cognitive Theory by Albert Bandura, and the Ecological Systems Theory of Human Development by Bronfenbrenner. (1994). Albert Bandura (1989) in his Theory of Cognitive Social posited that a child learns by observing others and there is a relationship between personality, learning, behavior, and the social environment. According to Bandura, observational learning by a child takes place as a consequence of observation of the behavior of others. Children often tend to imitate other people's behavior, the listening skills displayed by someone at home, school or society, and cyberspace. (Bell: 2014).

Modeling learning or example implies learning by observing the results of other people's activities be it appreciated, praised or discouraged and punished. According to Bandura (1989), learning through modeling takes place by four activities: Mindfulness (observing model behavior), Retention (transferring information to memory), Reproduction (mimicking model behavior) and Motivation (direct, representative and reinforcement). For early childhood, the models were parents and close family members who are always there. As per triadic behavioral models, behavior is the function of affective, cognitive and biological aspects of a person's personality, and the environment around the individual. While at home, parents spent a lot of their time doing official and personal work online using digital media gadgets. Young children observed their 'models' very closely and are influenced to mimic the habits and activities of their parents and family members which impact their behavior and learning process. (Lauricella, Wartella, \& Rideout: 2015).

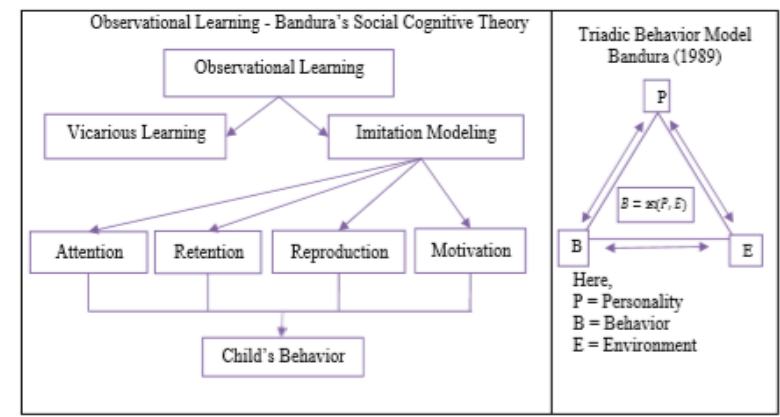

Figure 1. Social Cognitive Theory and Triadic Behavior Model (Bandura: 1989).

Learning a child's behavior can also be explained by the Ecological Systems Theory of Human Development of Bronfenbrenner who argues that child growth and development occurs in a five-layer ecological system around the environment. Figure 2 shows the possibilities several peripherals of this system and their possible interactions in the learning process. 


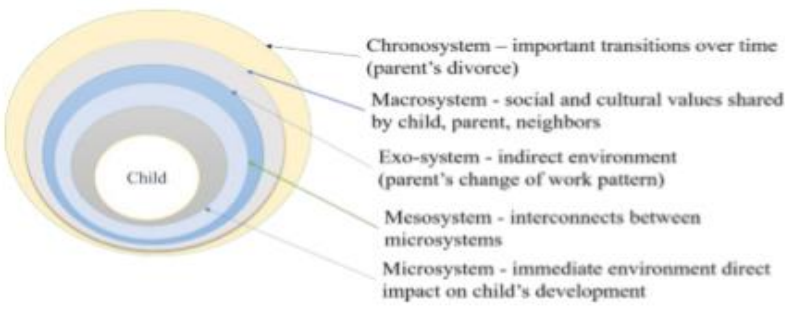

Figure 2. Ecological Systems Theory of Human Development (Bronfenbrenner, 1994).

These systems have direct and indirect influences in a child's developmental processes as follows:

1. Microsystems is a direct fringe around the child that includes the child, immediate family, teachers at school, and peers.

2. Mesosystem refers to the interconnection between these microsystems. The relationship between parents and the relationship between parents and teachers, and friends, has a big impact on the child's growth and development process.

3. Exo-system is the relationship between the social environment with less active roles, and direct context, for example, parental displacement, or changes in work patterns.

4. Microsystems encompasses a culture that is a collective environment involving children, parents, schools, and environments that share the same values and beliefs.

5. Chronosystem describes patterns of environmental and transition events such as divorce between parents, or significant changes in the social climate.

According to Lauricella (2015), micro systems are the most important layer in a child's learning process and some activities have significant traces referred to as 'molars'. The frequent use of media devices by parents can be referred to as molar activity that attracts children (Ameenuddin, et al:2016). Research shows that it is possible that violent content in media, cartoons, and video games can have a devastating impact on children. According to Lauricella (2015), very few study the impact of the use of digital media devices among children by the parents.

The amount of time spent on different types of technology or digital media in children tends to vary according to their age, meaning very young children tend to spend less time on digital media. The results of a study conducted by Lauricella, et al. (2015), in 2011, found that the use of computers by children up to the age of 8 years slightly increases with age. It was also found in 2013 that, the availability of diverse options allowed younger children (under 8 years of age) to spend more time with smart digital devices (38 percent of children under 2 years old, 80 percent of children under 4 years old, and 83 percent of children aged 5-8 years).

According to Bandura (1989), people can create and show a preference for the environment through their actions. Thus, older children tend to show their preferences when they can choose from a variety of options with a certain level of freedom. It is thought that children of the higher age group would prefer to spend more time with digital devices as they are faced with higher choice and greater freedom to choose.

The use of gadgets in this digital era has an influence on early childhood development, both positively and negatively. Some of the positive impacts of using this gadget are: (1) Information is easier to obtain and find practically, both domestically and abroad. (2) Communication to others is easy to do using the benefits of groups on social media. (3) Learning is more innovative because learning resources and information can be found easily on the internet. In addition, the availability of learning resources, such as online articles and electronic books (eBooks) is very easy to get on the internet.

The negative impact of the use of this gadget there are several things that must be minimized by parents, namely: (1) The lack of digital literacy, which is the negative impact of children who are used to insulting and being jealous of others who make them become depressed, get carried away by negative currents and speak less politely (Pratiwi \& Pranova: 2017); (2) Children think instantly. In general, children in this era tend to use online media to get information, so if you need deep thought, then they enjoy it less. (3) Gadgets can make children less active in the area, such as moving and exercising. It even makes them forget the time and pay less attention to their health. (4) Gadgets can cause addictions that make children become restless, uncomfortable, anxious, irregular sleep patterns, and tantrums when kept away from gadgets. (5) A consumptive lifestyle and relying on online media to complement his needs. (6) Negative content in online media such as Youtube or other social media that affects children's behavior (Maulidiyah: 2018).

\subsection{Child Care in the Digital Age in Instilling Sociocultural Values}

Parents have obligations in child care and education. The responsibility carried by parents in educating 
children to instill sociocultural values is governed by the Qur'an and Hadith. There are several verses of the Qur'an that discuss this parenting as in QS. An- Nisa: 9 that reads:

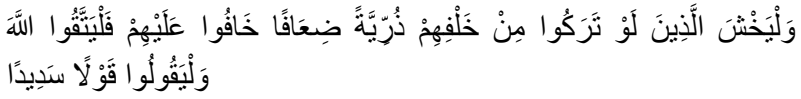

Translation: "And fear Allah those who, if they had left behind them weak children, who feared for their welfare. So let them fear Allah and speak the truth." (https://tafsirq.com/4-an-nisa/ayat-9, 2021).

This verse explains that parents must have a full responsibility to educate their children well so that children become strong and have a prosperous life. Parents are also commanded by Allah SWT to keep their families from the fire of hell. This is as in QS. At-Tahrim: 6 , which reads:

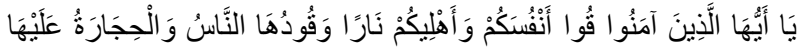

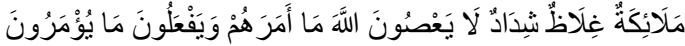

Translation: "O you who believe, protect yourself and your families from the fire of hell whose fuel is man and stone. His guardian angels are rude, hard, and do not disobey God to what He commanded them and always do what he is commanded." (https://tafsirq.com/66-attahrim/ayat-6: 2021).

Allah commands parents to teach their children to pray and be patient. This is as in QS. At-Thaha: 132, which reads:

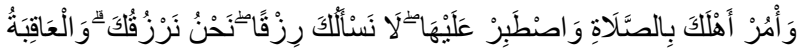
لِلنَّقَْى

Translation: "And command your family to pray and be patient in doing so. We do not ask you for sustenance, we are the ones who give you sustenance. And the consequences are for those who fear." (https://tafsirq.com/topik/thaha+ayat+132: 2021)

Some of the above verses of the Qur'an are very important to be understood by parents in childcare. In addition to the Qur'an, the Prophet's hadith also describes the education of children, such as (1) "A person who educates his child is better than giving alms with one sha", (2) "There is no gift from a parent to a better child than a good one." (3) "Educate your children over three things; Love your Prophet, love his temple and read the Qur'an.” (HR. Ath-Thabrani)

Based on the guidelines set out in the Qur'an and Hadith, parents should care for and guide children wholeheartedly. Parents must also instill sociocultural values in the daily life of children, both the practice of worship and the formation of morals. This is certainly intended so that the child has a good sense of responsibility towards him, carries out his obligations properly based on the teachings of Islam, and feels always supervised by Allah SWT at all times. Some of the parental responsibilities that must be given to their children are the responsibility of faith education, moral education, physical education, psychiatric education, social education, and sex educators (Ulwan: 2012). The cultivation of sociocultural values is becoming increasingly important in overcoming the negative impacts that occur in this digital era.

Early childhood living in this era cannot be separated from the use of gadgets. Based on the results of interviews conducted with 10 respondents, 9 out of 10 respondents gave gadgets to their children who were still at an early age. While 1 respondent did not give gadgets to his child at all because his son was still 15 months old. However, his son still was instilled sociocultural values from an early age by reading books that are rich in Sociocultural values before going to bed. (Qadafi, Wawancara: 2021).

Based on the results of interviews conducted by researchers, parents who give gadgets to their children were caused by parents or the environment around children who often use gadgets. Children observed the behavior of parents and adults around them. The gadgets used were smartphones, televisions, laptops, and tablets. The use of gadgets in early childhood is very helpful for the busyness experienced by their parents. Usually, children who are given gadgets will focus more on what they see.

Parents who gave gadgets to early childhood among several different respondents, some were given to newborn children, and there were children given at the age of 4 years. Giving gadgets to his child was done by the father and mother, even his uncle, and became part of parenting. Children who used gadgets based on the results of interviews and observations conducted by researchers, there were children who are addicted to gadgets, but parents considered it not a problem. There were children who use gadgets to accompany the child to eat, and there were also using them as entertainment after learning. Nevertheless, parents still limited the use of gadgets on their children.

Some parents believe that children born in this era are the digital generation, so introducing digital or gadgets to children is not a big problem. Plus, children 
are able to operate digital or gadgets naturally without the help of parents. Based on the results of observations and interviews conducted by researchers, gadgets are useful in instilling sociocultural values, for example: children can learn daily doá-doá from youtube videos. In addition, children can also practice other worship such as prayer, fasting, almsgiving, and so on from these gadgets. According to Mrs. Halimah.

"Children born in this era are the digital generation (digital native) because they can search for content on Youtube without being taught by their parents. Through gadgets, children understand about how to fast, pray, close aura, and memories daily prayers."

Basically, all respondents who researchers interview and observation want to have a good and noble child, so they instill sociocultural values according to their ability. Of course, the cultivation of sociocultural values is easier to do by utilizing gadgets in parenting. However, sociocultural values taught and obtained from gadgets are not only the practice of worship, but actions that are loaded with early childhood moral development, such as habituation to say the words "sorry", "please", and "thank you". Usually, children are easier to imitate when their idols or watch results do the same thing.

Gadgets can be an interesting learning medium, as they are accompanied by varied images, interesting content and sounds, as well as a very large viewing program. Through gadgets also children can learn to filter themselves, for example, children become embarrassed not to close the aurat when watching open shows. In addition, parents can also teach the values of faith, honesty, responsibility, and discipline to children. Good parents, despite giving gadgets to their children always make a deal at the beginning, such as how long to watch the gadget, and what content can be watched. Parents who care about children mean parents who are involved in the entire dimension of the formation of a child. That is, parents are not only good and understand all kinds of things and technical terms of digital devices and media that will be purchased or used by children. However, as long as the child is still dependent on the parents, then parents must know, not limit, what and how digital devices and media are used by children (Fatmawati: 2019). This is done to prevent children's addiction to gadgets, because if it is addicted, it can make children unruly and easy tantrums.

\section{CONCLUSION}

Gadgets have their own anxiety experienced by parents. Inevitably, children in this era will be exposed to gadgets. Even though there are many negative impacts of the gadget itself, gadgets can ease the burden of parents in the parenting process. In addition, children can also learn various things using gadgets, including in learning about sociocultural values. Wise parents will still introduce gadgets to early childhood, but still be given limits so as not to cross the line and addiction that makes children become tantrum and unruly.

\section{AUTHORS' CONTRIBUTIONS}

All authors conceived and designed this study. All authors contributed to the process of revising the manuscript, and in the end, all authors have approved the final version of this manuscript.

\section{REFERENCES}

[1] R. Antar. Exnloring the use of electronic media in voung children's lives and its effects on brain develonment. Journal of Earlv Childhood Education Research 8(1), 2019, pp. 59-73.

[2] H. Baharun. F.D. Finori. Smart Techno Parenting: Alternatif Pendidikan Anak Pada Era Teknologi Digital, Jurnal Tatsqif 17(1), 2019, pp. 52-69.

[3] A. Bandura. Social Cognitive TheorvAnnals of Child Develonment. Volume 6. Six theories of child development R. Vasta Greenwich, CT. 1989.

[4] J. S. Bell. A aualitative look at middle SES preschoolers: media consumption and social behaviors, 2014.

[5] S. R. Brady, Utilizing and adapting the Delphi method for use in qualitative research. International Journal of Qualitative Methods 14(5), 2015, pp. 1609406915621381

[6] U. Bronfenbrenner. Urie. Ecological models of human develonment. Readings on the development of children 2(1), 1994, pp. 37-43.

[7] N. I. Fatmawati, Literasi Digital, Mendidik Anak Di Era Digital Bagi Orang Tua Milenial, Jurnal Politik Dan Sosial Kemasyarakatan 11(2), 2019, pp. 11938 .

[8] Council on Communications and Media. and MBE Media use in school-aged children and adolescents. Pediatrics 138(5), 2016, pp. e20162592.

[9] https://tafsirq.com/4-an-nisa/ayat-9, diakses tanggal 31 Januari 2021.

[10] https://tafsirq.com/66-at-tahrim/ayat-6, diakses tanggal 31 Januari 2021. 
[11] https://tafsirq.com/topik/thaha+ayat+132, diakses tanggal 31 Januari 2021.

[12] M. Keumala. M. Yoestara. Z. Putri. The Imnacts Of Gadget And Internet On The Imnlementation Of Character Education On Earlv Childhood. In International Conference on Early Childhood Education, 2019, pp. 313-325.

[13] V. Konok. N. Bunford. Á. Miklósi. Associations between child mobile use and digital narenting stvle in Hungarian families. Journal of Children and Media 14.(1), 2020, pp. 91-109.

[14] A. R. Lauricella. E. Wartella. V. J. Rideout. Young children's screen time: The comnlex role of narent and child factors. Iournal of Annlied Developmental Psychology 36, 2015, pp. 11-17.

[15]M, Sundus. The Impact of Using Gadgets on Children. Journal of Depression and Anxiety 07, no. 01 (2017): 1-3. https://doi.org/10.4172/21671044.1000296.

[16]S. Maisari. S. Purnama. Peran digital narenting terhadan nerkembangan bernikir logis anak usia 5-6 tahun di ra bunavva giwangan. AWLADY: Jurnal Pendidikan Anak 5(1), 2019, pp. 41-55.

[17] M. S. Masrur. A. Amri. Nilai-nilai Pendidikan Islam dalam Film Animasi Nussa Enisode Sholat Itu Wajib, PALAPA 9(1), 2021, pp. 55-75.

[18]E. C. Maulidivah. Penanaman nilai-nilai agama dalam nendidikan anak di era digital. Martabat 2(1). $2018 . \quad$ pD. 71-90, https://doi.org/10.21274/martabat.2018.2.1.71-90

[19]A. J. Mills. G. Durenos. E. Wiebe. eds. Encvclonedia of case study research. Sage Publications, 2009.

[20] M. M. Neumann. Young children and screen time: Creating a mindful annroach to digital technology. Australian educational computing 30(2), 2015.

[21] N. Nirwana. A. M. Manpapoleonro. Chairunnisa. The Effect of Gadget Toward Earlv Childhood Sneaking Abilitv. Indonesian Journal of Earlv Childhood Education Studies 7(2), 2018, pp. 85-90.

[22] M. A. Oun. C. Bach. Oualitative research method summary.Qualitative Research 1(5)2014, pp. 252258.

[23] N. Pratiwi. N. Pritanova. Pengaruh literasi digital terhadan nsikologis anak dan remaja. Semantik 6(1), 2017, pp. 11-24.

[24] D. N. Sari. An Analvsis of the Imnact of the Use of Gadget on Children's Language and Social Develonment. International Conference of Earlv Childhood Education (ICECE 2019), Atlantis Press, 2020, pp. 201-204.

[25] M. Smahelova. D. Juhova. I. Cermak. D. Smahel. Mediation of voung children's digital technologv use: The narents' nersnective. Cvbernsvchologv: Journal of Psvchosocial Research on Cyberspace 11(3), 2017.
[26] D. Sugivono. Metode nenelitian nendidikan pendekatan kuantitatif, kualitatif dan R\&D, 2013.

[27]N. Ulwan. Pendidikan Anak Dalam Islam. Teriemahan Arif Rahman Hakim, Solo: Insan Kamil, 2012.

[28] S. Yoruk, I. Cankaya, A Qualitative Research on the Effect of Internet Games and TV Series on Primary School Students' Perceptions of Violence', International Journal of Social Science \& Education, vol. 4, no. 1, 2013: 167-173. 